\title{
Annlee; or, Transposition as Artistic Device
}

\author{
Leif Dahlberg \\ School of Computer Science and Communication, \\ Royal Institute of Technology (KTH), Stockholm
}

ars adeo latet arte sua - Ovid $^{1}$

This essay discusses transposition as an artistic device, taking as an example the collaborative project Annlee (1999-2003), initiated by French artists Pierre Huyghe and Philippe Parreno, focusing in particular on Huyghe's animated film One Million Kingdoms (Huyghe 2001). It is argued that transposition is a key element in the construction of the artwork but also a theme in itself, establishing what Amelia Barikin (2012) has aptly called "parallel presents."

In 1999, Huyghe and Parreno bought the copyright for a manga figure from the Japanese firm Kworks for forty-six thousand Yen (approximately four hundred US dollars at the time). In an interview, Parreno said that they were looking for "a character without a name, a two-dimensional image, with no turn-around. A character without a biography and without qualities, very cheap, which had that melancholic look, as if it were conscious of the fact that its capacity to survive stories was limited" (Huyghe et al. 2003, 15). Independently and also together with other artists and producers, Huyghe and Parreno then produced a number of animated films and other artworks featuring this character, which they had given the name Annlee. The two first productions were Huyghe's animated film Two Minutes Out of Time (200o) and Parreno's film Anywhere Out of the World (2000), in which Annlee speaks of her various identities as a commodity, a visual sign (without her own voice), and a supernumerary female character. Already in these two films Annlee is being transformed from a ready-made to a remake, something she herself comments on. Parreno has described the two films as "non-fiction," constituting "the preface to a real story. By freeing the character from the fiction market, it became an empty shell" (Huyghe et al. 2003, 16). This statement is in itself rather paradoxical, since by giving the character a name, making her speak and speak about her alienated situation, she becomes not an empty sign but a persona, a mask reflecting on its situation on the screen (much like the characters in Luigi Pirandello's Sei personaggi in cerca d'autore [Six Characters in Search of an Author, 1921]). In other words, Annlee's ability to reflect on her situation makes her remarkably alive, whereas previously she had indeed been but an empty shell. Moreover, in effecting a displacement from popular

1 Metamorphoses $10.25^{2}$ (Ovid 2014, 27). 


\section{Leif Dahlberg}

culture to serious culture and from East to West-that is, a transposition from one fictional and cultural realm to another-Annlee lost her bearings and became doubly alienated. After being introduced into the art world, she now acquired a more substantial personality in the hands of a series of artists who were invited to work with her and bring her to life.

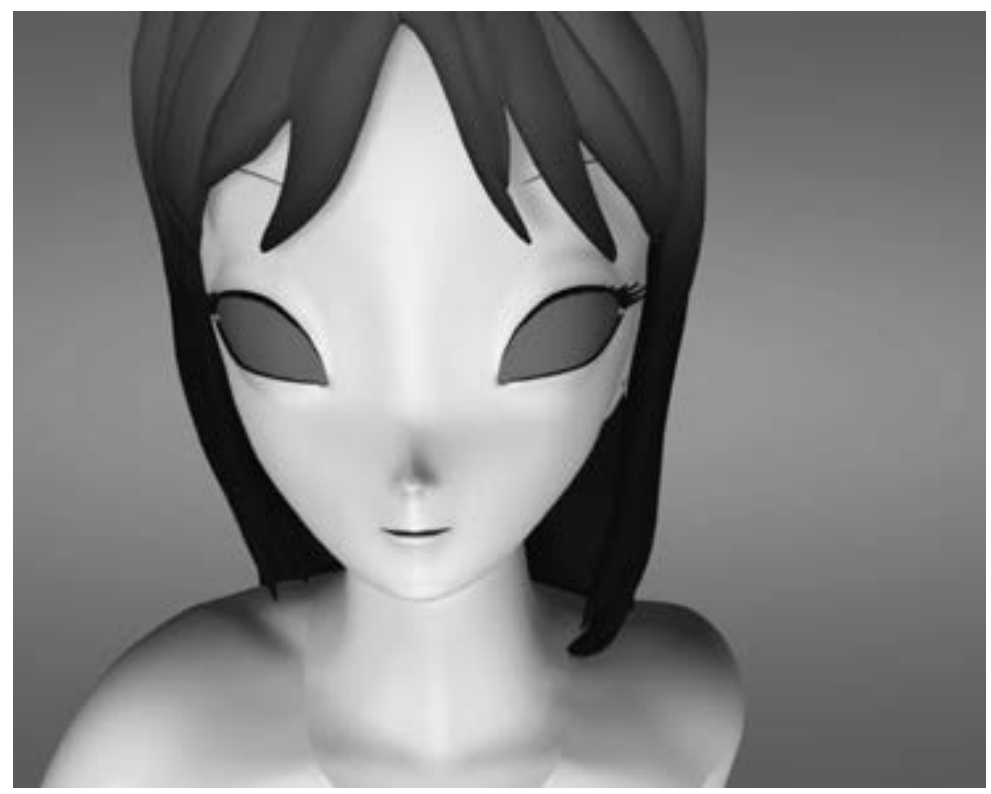

Fig. 6.1

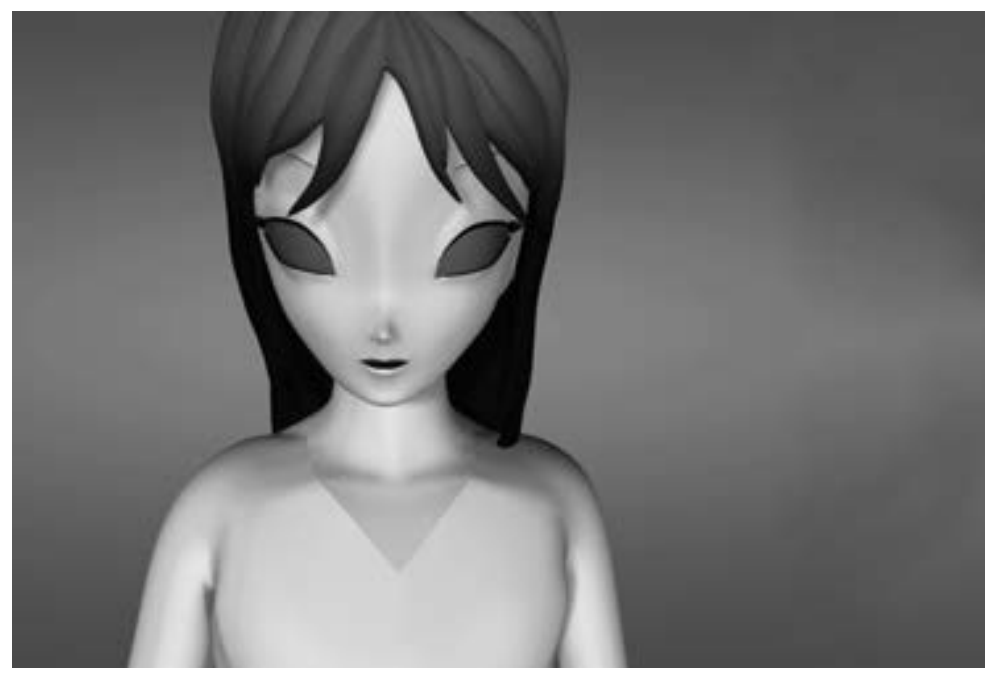

Fig. 6.2 
The artwork that I focus on in this essay is the film One Million Kingdoms, directed by Huyghe and produced by Anna Lena Vaney. Huyghe has described the film as the narration of a "non-realised project, Apollo o" (Centre Pompidou 2013, my translation). ${ }^{2}$ In this animated film we follow a lonely female figureAnnlee-walking through a digitised moonscape drawn by the graphic waves produced by the synthesised voice of American astronaut Neil Armstrong, reading a text written by Huyghe including extensive citations from Jules Verne's 1864 novel Voyage au centre de la terre (Journey to the Centre of the Earth). ${ }^{3}$ Before Annlee appears in the film, the screen shows an animated diagram of the earth and the moon. The first thing to appear, at the top of the earth, is a schematic volcano, and, on the left side of the earth at the level of the equator, a surface indicated as "Expedition departure 1998." From the latter, a dotted line is drawn to the volcano, now identified as "Snœeffels Jokull" in Iceland and described as "Moon test area." From here a dotted line is made to the centre of the earth (indexed "Journey to the Centre of the Earth 1865"). From the volcano, a new dotted line is drawn up to the moon (now indexed "Moon landing 1969 "). Then there appears another moon, located bottom right of the earth, to which is drawn another dotted line from the surface indicated as "Expedition departure 1998." Finally, there appears the legend "No ghost just a shell 2001" next to this other moon. During this opening animation, a text runs along the bottom of the screen that reads, "The Journey to the Centre of the Earth by Jules Verne begins in Iceland, in the Snoffels Jokull crater at the north of the island. The conquest of space starts there on that same desert of lava. The first images of Neil Armstrong hopping in his space suit in the middle of a desolated landscape were first shot there. This is an expedition through territories topologically similar." This text connects the 1969 moon landing with the Snæfell volcano on Iceland, which was the place where Verne's adventurers entered the underworld and also where the American astronauts had practised moonwalking. There is a transposition of the journey to the centre of the earth (Verne) to the voyage to the moon (Apollo 11). The text states that these journeys are "topologically similar." As has been noted by Barikin (2012, 183-86 et passim), Huyghe has a long-standing interest in topology, the mathematical study of relations of forms in space. In an interview Huyghe has stated that this interest stems from a desire "to translate an experience without representing it. The experience will be equivalent and still it will be different" (Baker and Huyghe 2004, 92). "When you translate something, you always lose something that was in the original. In a topological situation, by contrast, you lose nothing; it is a deformation of the same" (ibid., 91). In the film, the Icelandic volcano serves not only as a meeting place of two topologically similar explorations but also

2 "Pierre Huyghe le décrit ainsi: 'Annlee est la narratrice d'un projet non réalisé, Apollo o. Le personnage marche dans un paysage dessiné par des courbes graphiques produites par sa voix. Il se déplace dans ce qu'il énonce. Sa voix est synthétique, elle a été obtenue à partir de celle de Neil Armstrong."

3 The text of the soliloquy is reproduced in the catalogue No Ghost Just a Shell (Huyghe and Parreno 2013, $142-45$, with some slight differences. 


\section{Leif Dahlberg}

as a mirroring of science and science fiction. The topological transformation thus has the form of a double transposition, where the fictional journey to the centre of the earth becomes equivalent to the real voyage to the moon, which in turn initiates Annlee's trip to the moon.

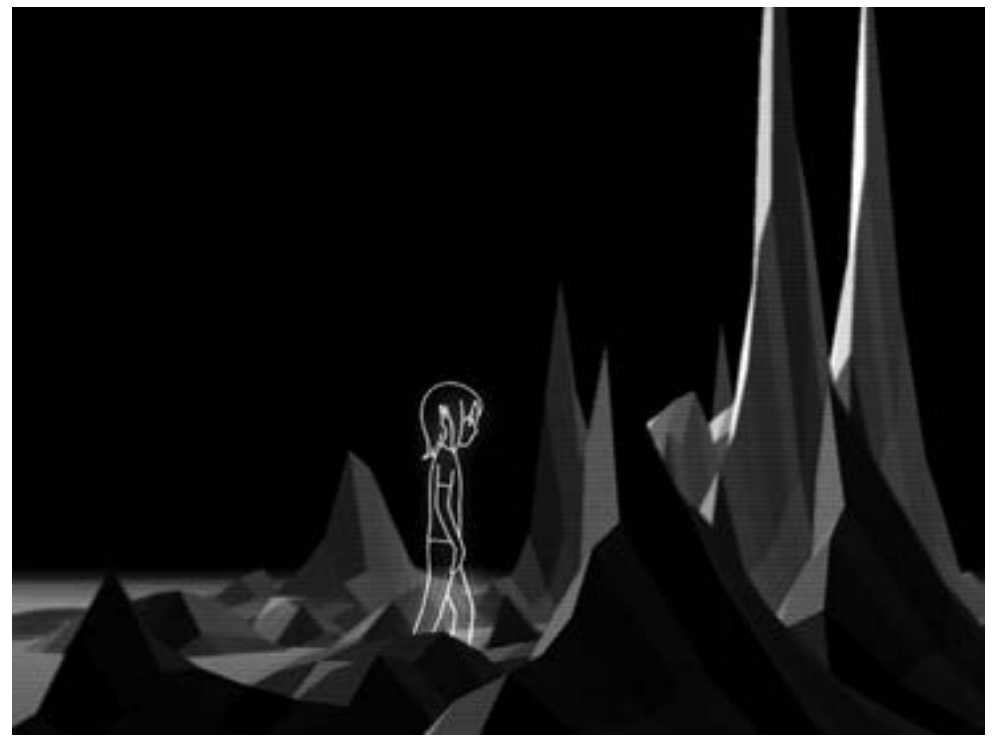

Fig. 6.3

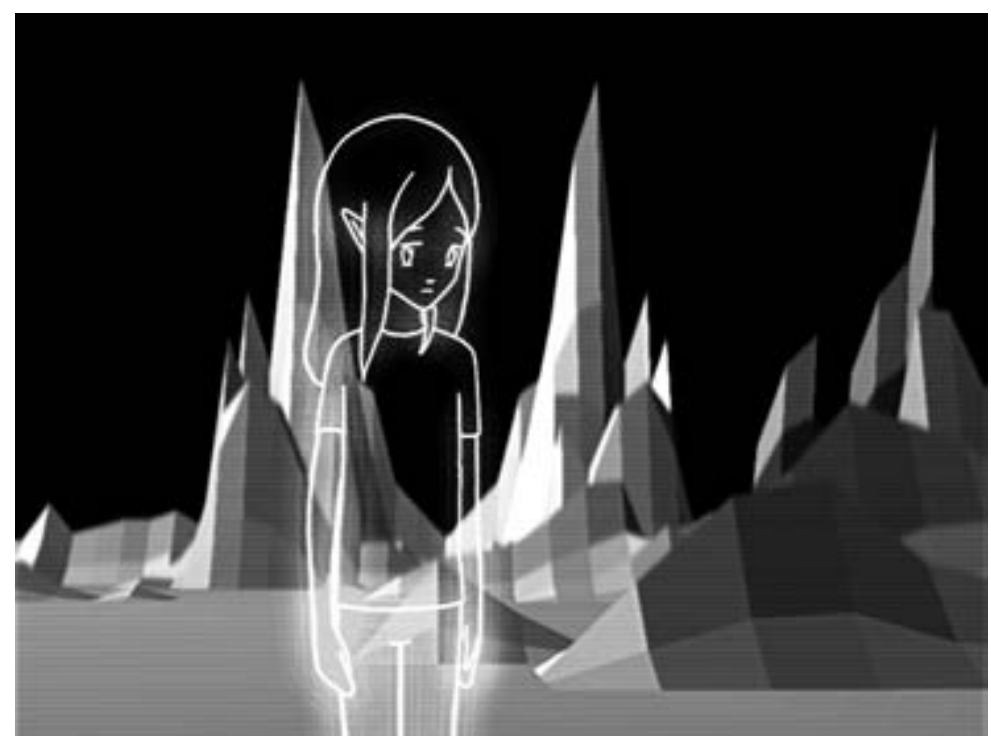

Fig. 6.4 
In the film, the synthesised voice, which both belongs to and does not belong to Armstrong, also belongs to the animated female figure-we see her lips moving synchronised with the voice-walking through the landscape that the voice generates. The moonscape is also a voicescape. This creates a confusion of identities: first, the identity of Armstrong himself, lending his synthesised (male) voice to a female character; second, Annlee, who by this feat becomes transgendered, speaking with a male voice; and, third, of the moonscape itself. In English, as in Latin and French, the moon is a "she," 4 but in the film it appears rather as masculine (as in Germanic mythology and in the German language) as it is produced by the male voice. How should we understand these transpositions of genders? And how is this related to the other transpositions we have encountered so far: from East to West, from popular culture (manga, Jules Verne) to serious culture, from the journey to the centre of the earth to the voyage to the moon, from the test site on Iceland to the moon landing, from fiction to reality, from text to voice and voice-over narration as soliloquy, from graphic waves to moonscape? It seems that transposition is not only a recurring pattern in the film but a construction plan, a blueprint of how the artwork is conceived and put together.

In rhetoric, transposition (or transmutatio) denotes the operation of changing the normal order or arrangement of verbal elements, but it can also be used to describe the operation or function of metaphor (Ricœur 1975, 34-40)..$^{5}$ Most of the transpositions in the film have indeed the character of metaphor-the volcano crater is like a lunar landscape, the descent into the underworld is like the flight to the moon-yet the meaning of a sign changes when placed in a different context: two (radically) different contexts are brought into contact with

4 In Latin and French this is evident from the gender of the word, whereas in English it appears in discourse, as, for example, in book 4 of John Milton's Paradise Lost, lines 29-30 and 605-9 (Milton [1674] $2004,85,102)$

Sometimes towards heaven and the full-blazing sun,

Which now sat high in his meridian tower

Hesperus that led

The starry host, rode brightest, till the moon

Rising in clouded majesty, at length

Apparent queen unveiled her peerless light,

And o'er the dark her silver mantle threw.

Or in W. S. Gilbert's libretto for The Mikado, first performed in 1885 (Gilbert 1992, 24-25):

The sun, whose rays are all ablaze with ever-living glory,

does not deny his majesty-he scorns to tell a story!

He don't exclaim, "I blush for shame, so kindly be indulgent."

But, fierce and bold, in fiery gold, he glories all effulgent!

I mean to rule the earth, as he the sky-

We really know our worth, the sun and II

Observe his flame, that placid dame, the moon's Celestial Highness;

There's not a trace upon her face of diffidence or shyness:

She borrows light that, through the night, mankind may all acclaim her:

And, truth to tell, she lights up well, so I, for one, don't blame her!

5 For a philosophical discussion of the relation between metaphor and (conceptual) knowledge, see Derrida ([1971] 1972); Ricœur 1975 (356-74 et passim). 


\section{Leif Dahlberg}

each other. However, some of the transpositions are metonymical-as when the graphic waves of Armstrong's voice are turned into a physical landscape. This kind of metonymy has been called "metalepsis of the author," a figurative inscription of the speech act in the work itself. To quote French rhetorician Pierre Fontanier ([1827] 1977, 128, my translation), it is "the figure by which a poet, a writer, is represented or represents himself as producing that which he in reality is only narrating and describing." Although in this case there is a certain confusion as to who is the author/writer (Verne, Armstrong, Annlee, Huyghe), within the fiction of the film it is the voice of Armstrong, spoken by Annlee, that generates the lunar landscape. The effect of metalepsis on the one hand underlines the fictional character of the work, that the character's voice is able to generate a physical landscape, which makes the separation between subject and object precarious. ${ }^{7}$ On the other hand, the rhetorical figure also has the effect of rendering the fiction real, since it itself appears to be able to create things. In other words, the mise-en-abyme structure has dual effects, destabilising the distinction between reality and fiction. This kind of topological inversion of fiction and reality is a recurrent theme in the artworks of Huyghe and Parreno, and to some extent appears to be motivated by an engagement with Guy Debord's critique of "the society of the spectacle" (see Godfrey 2008; Erickson 2009; Barikin 2012, 16-19, 46).

In the above description of One Million Kingdoms, we have thus established that the film narrative is constructed-diegetically and non-diegeticallythrough a series of transpositions, making transposition the operative device and material theme of the film. In exploring transposition as an artistic and aesthetic device, the analysis of Huyghe's film also needs to scrutinise the dialogic dimensions of transposition. But before investigating the intertextual mechanics of the film, a few other works produced under the banner of Annlee should be mentioned: Dominique Gonzalez-Foerster's animated film Ann Lee in the Anzen Zone (2000), in which the character speaks in Japanese about there being no "safe zone" (anzen zone, in Japanese); Huyghe's and Parreno's neon sculpture Skin of Light (2001); and Liam Gillick's video (in collaboration with Lars Magnus Holmgren) Annlee You Proposes (2001), which has the form of a trailer for a longer narrative. Yet another work is Rirkrit Tiravanija's eight-and-a-halfhour film Ghost Reader C. H. (2002), in which Annlee reads the entire text of Philip K. Dick's science fiction novel Do Androids Dream of Electric Sheep? (1968). ${ }^{8}$ The novel, perhaps more widely known in the film adaptation by Ridley Scott, Blade Runner (1982), is set in a not too distant, post-apocalyptic future. The story

6 "Le tour par lequel un poète, un écrivain, est représenté ou se représente comme produisant lui-même ce qu'il ne fait au fond, que raconter ou décrire." For an extensive discussion of metalepsis, see Dahlberg (2010).

7 This brings to mind certain scenes in the 1956 science fiction film Forbidden Planet (directed by Fred M. Wilcox). The film is loosely based on William Shakespeare's The Tempest and is also informed by Freudian notions of the unconscious. In the scenes in question, creatures of the unconscious are being (inadvertently) materialised through an electronic device, creatures that in turn threaten the survival of the residents.

8 An excerpt of Philip K. Dick's novel is reproduced in the exhibition catalogue to the exhibition No Ghost Just a Shell (Huyghe and Parreno 2003, 197-99). 
follows a bounty hunter (Rick Deckard) who is faced with killing ("retiring") six escaped androids who have returned to earth from slave labour in off-planet colonies. The novel explores the question of what it is to be human, in particular the difference between human intelligence and artificial intelligence. In the story, we encounter androids who are unaware they are not the real thing since they have been provided with false childhood memories-but also the reader/viewer becomes increasingly uncertain whether apparently animate objects really are alive or not, and, conversely, whether lifeless objects might not perhaps be animate. In other words, the reader/viewer experiences what psychologists Ernst Jentsch (1906) and Sigmund Freud ([1919] 1966) identified as disquieting strangeness or the uncanny (das Unheimliche). ${ }^{9}$ Annlee's reading of this novel puts another twist to Dick's story, since she herself is a visual sign becoming animated.

In the process of making these films and other artworks in various media, Annlee's graphic features gradually evolved, but, more importantly, the figure had come to develop a complex personality of its own. Also, from having been designed as a minor figure for manga comics, Annlee now had become an international celebrity. Thus it is tempting to compare her situation to that of the female protagonist in Bernard Shaw's Pygmalion (1913), in which a simple flower girl from Covent Garden is refashioned to pass for a duchess. But perhaps a better comparison is to the development of Don Quixote in Cervantes's novel. As has been noted by Viktor Shklovsky (1990b, 73-74), Don Quixote was conceived by the author to be a person of rather limited intelligence; but, as the novel progressed, Cervantes found that "he needed Don Quixote as a unifying thread of wise sayings" (ibid., 73). In this way there emerged in the character a duality - between simple mindedness and wisdom - a fact that Cervantes started to exploit halfway through the novel (ibid., 8o). As we will see later on, Huyghe and Parreno would deal quite differently with the psychological development of Annlee.

The metamorphosis of Annlee thus stands in sharp contrast to the faceless character she had been when purchased by Huyghe and Parreno. Some of these developments are commented upon in the catalogue to the exhibition No Ghost Just a Shell (Huyghe and Parreno 2003), in which all the works produced

9 In "Zur Psychologie des Unheimlichen" (On the Psychology of the Uncanny), Jentsch writes: "Among all the psychical uncertainties that can become a cause for the uncanny feeling to arise, there is one in particular that is able to develop a fairly regular, powerful and very general effect: namely, doubt as to whether an apparently living being really is animate and, conversely, doubt as to whether a lifeless object may not in fact be animate- and more precisely, when this doubt only makes itself felt obscurely in one's consciousness" (Jentsch 1906, 197, as translated in Jentsch 2008, 221). "In storytelling, one of the most reliable artistic devices for producing uncanny effects easily is to leave the reader in uncertainty as to whether he has a human person or rather an automaton before him in the case of a particular character. This is done in such a way that the uncertainty does not appear directly at the focal point of his attention, so that he is not given the occasion to investigate and clarify the matter straight away; for the particular emotional effect, as we said, would hereby be quickly dissipated" (Jentsch 1906, 203, as translated in Jentsch 2008, 224). Both quotations appear in Freud's "Das Unheimliche" ("The Uncanny") ([1919] 1966, 237, 238). 


\section{Leif Dahlberg}

in the project were brought together. ${ }^{10}$ For the polyphony of the project-that is, that several different artists became authors of the "same" work- the essay by Maurizio Lazzarato (2003) on Mikhail Bakhtin is significant. A key idea of Bakhtin is that the spoken word is inherently dialogic and open to a multiplicity of meanings, which are activated in social intercourse, a view that is radically different from the monologism predominant in linguistics. It is also important to note that the meanings of utterances are not exclusively dependent on a given context; they themselves contribute to shaping the social world, just as Annlee's soliloquy generates the lunar landscape through which she walks. Although Annlee initially was a visual sign, she soon became a multimodal sign, or rather a complex of signs, which was being addressed and remade by a series of artists. The inclusion of Lazzarato's essay on Bakhtin in the exhibition catalogue suggests that we should understand her also as a dialogic sign. What does this mean?

In Bakhtin's readings of Fyodor Dostoyevsky's novels, close attention is paid to the social contexts in which actions and events take place and that utterances always need to be read against who says what to whom, when and where (Bakhtin 1984; see also Bakhtin 1981). Bakhtin is particularly interested in how different characters function as ideologues for clashing worldviews. The spoken and written word (or "utterance" for short) communicates with other utterances, both inside and outside the immediate context; it is radically dialogic. This form of dialogic reading opens the literary text to topological transformations, where the voices and utterances of characters are allegorically superimposed, as in Annlee's soliloquy in One Million Kingdoms. I will take this invocation of Bakhtin as a cue, and legitimisation, to perform a dialogic reading of Annlee's lunar soliloquy.

As we have already seen, the beginning of the film establishes a connection between the descent into the underworld in Verne's novel and the 1969 moon landing. There are however a number of other parallels that also suggest themselves. First, to Georges Méliès's 1902 film Le Voyage dans la Lune (A Trip to the Moon), inspired by other novels by Verne. Second, Verne's fantastic description of the descent into the netherworld has a long literary lineage, including Odysseus's visit to Hades (Homer's Odyssey, book 11), Aeneas repetition of this feat (Virgil's Aeneid, book 6), and Dante's thematic elaboration in Inferno (1320). In particular, Virgil is invoked several times in Verne's novel, both directly and indirectly. ${ }^{11}$ Further, there exist a great number of popular fictions about travelling to other planets. But if the topos is already overdetermined to begin with, what is interesting is what Huyghe makes of it, how he transforms it.

10 No Ghost Just a Shell, Kunsthalle Zürich, 24 August-27 October 2002; SF MOMA, San Francisco, 14 December 2002-16 March 2003; Van Abbemuseum, Eindhoven, 19 January-August 2003.

11 For example, at the end of chapter 11 ("Et quacumque viam dederit fortuna sequamur" [The Aeneid 11.128, quoted in Verne (1864) 1919, 97; 1992, 6o]), in chapter 18 ("facilis descensus Averno" [The Aeneid 6.126 , quoted in Verne $(1864) 1919,149 ; 1992,92])$, and through the ciceron of the underworld, Hans Bjelke ("Ce personnage grave, flegmatique et silencieux" [Verne (1864) 1919, 90, as translated in Verne 1992, $5^{6}$; This serious, phlegmatic, silent type]). For a thorough analysis of the presence of Virgil in Verne, see Stevens (2015). 
Annlee's lunar monologue can be divided into three parts: the first part is mainly authored by Huyghe, based on pictures and films of the test site on Iceland and the astronauts' accounts of the moon landing, as well as subsequent re-evaluations of the Apollo project; the second part is made up of quotations from the beginning of chapter 17 of Verne's novel; and the third part consists of two quotations from chapter 28 . The first part reads like this:

It's a lie!

It's there, at the foot of the volcano, that the moon-landing tests were filmed.

Before anyone walked on the moon, these pictures foreshadowed us what we would discover later on.

They prepare us for the spectacle of desolation.

On the moon, there is nothing besides dust...

The conquest of space, which was a dream until now ... had become an illusion.

We want to enter the unknown, when the greatest mysteries are right here ...

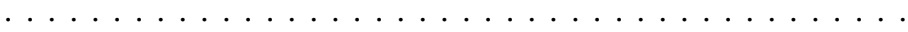

Here under our steps...

We are on the thresholds of another world, just one small step ... ${ }^{12}$

Although it has repeatedly been suggested by commentators that the text is based on Neil Armstrong's moon landing communiqués, there are only a few direct correspondences to the transcripts of the communication with ground control in Huston on 20 July 1969, or from the Apollo 11 post-flight press conference on 12 August the same year. ${ }^{13}$ Rather, the text seems to describe pictures of the test site in Iceland where the astronauts practised in July 1967. Perhaps Huyghe has used interviews with Armstrong or other astronauts who visited the site; or perhaps he has just used poetic license (as did David Bowie in his song Space Oddity, 1969). The verbal echoes we do hear of the astronauts' communications after the moon landing are the description of the empty, desolate landscape ("magnificent desolation") ${ }^{14}$ where there is "dust" everywhere,

12 The text in the catalogue No Ghost Just a Shell (Huyghe and Parreno 2003, 143) is slightly different:

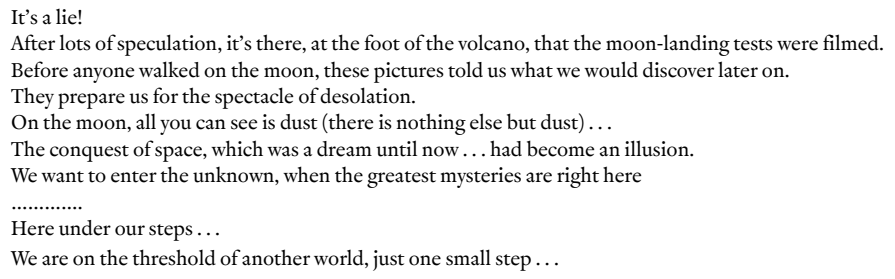

13 For instance the following description of One Million Kingdoms from the Guggenheim Museum in New York: "this brooding young girl [Annlee] speaks in a voice that is an electronically altered version of the astronaut Neil Armstrong's communiqués from the first moon landing; the text she recites conflates Armstrong's historic utterances with excerpts from Jules Verne's 1895 novel Journey to the Center of the Earth" (Guggenheim 2017). Another example: "The voice is a rearrangement of Neil Armstrong's recording during the Apollo 11 expedition.... The narration is inter-mingled with words from the real record of the lunar landing" (Zironi 2010, 224). For transcripts of the communication between the astronauts and ground control in Huston, see "One Small Step" (NASA 2012). For transcripts from the Apollo 11 post-flight press conference, see The First Lunar Landing (NASA 1989a).

14 However, this comment was made by astronaut Buzz Aldrin (see NASA 2012). 


\section{Leif Dahlberg}

and of course the first part of Armstrong's eternalised words, "That's one small step for [a] man, one giant leap for mankind." By contrast, the word "spectacle" is quite frequent in Verne's novel. ${ }^{15}$ The most striking connection with statements made by the Apollo 11 astronauts is however a response to a question at the post-flight press conference. A female reporter asked whether the astronauts felt "that there will ever be an opportunity for a woman to become an astronaut in our space program?" To which Armstrong replied succinctly, "I sure hope so." ${ }^{\prime 16}$ It could be argued that the appearance of Annlee on the moon, speaking with the voice of Armstrong, fulfils his desire; yet she does not look like an astronaut (she does not wear a space suit) and her luminous appearance makes her look more like a ghost than a real person.

Speaking of hope and desire, the first part of Annlee's lunar soliloquy thematises the relation between expectations-on the basis both of speculations and of physical preparations on earth-and their realisations in the desolate reality on the moon. Thus, what had been broached as a "conquest of space" brought back home only rocks and dust, and had indeed turned into an illusion. A few years later, in 1972, the Apollo programme would be terminated; no more manned trips were made to the moon. This difference between before and after should lead our attention to the temporal transpositions at work in this short text, already signalled by the temporal gap between 1864 and 1969 . Although it is unclear what the initial line refers to ("It's a lie!"), it is marked by the present tense. The following line continues in the same tense ("It's there"), but after the comma moves to past tense ("were filmed"). The following line continues in the past tense, yet at the same time it is a past that tells of future events, of what would be discovered. Thus the paradox that the past is in the present and that which would be discovered was already known. Is this the "lie" that the first line refers to? In any case, the next line moves back to the present, although it is the pictures that are the active agents ("they prepare us"). The following line, still in the present tense, reinforces the spectacle of desolation ("there is nothing besides dust"). The next line, although in past tense, refers to the present ("now")- that is, the present moment had been a dream until now-but in the moment of its realisation it had become an illusion (maybe even a lie). The following line, in the present tense, perhaps contains the truth of this illusion, this lie. The unknown that we seek elsewhere, in space, is already before us, under our steps. This would seem to refer to the descent into the underworld rather than taking small steps on the moon. But, at the

15 To give just some examples (emphasis added): "Je ne me doutais guère alors du spectacle qui nous attendait à la presqu'île du Sneffels" (Verne [1864] 1919, 101; as translated in Verne 1992, 63; I hardly realized at this stage what a sight awaited us on the Snæfells peninsula); "le spectacle d'une substruction basaltique ne s'était pas encore offert à mes regards" (Verne [1864] 1919, 114; as translated in Verne 1992, 71; I had never actually seen the display of a basalt construction); "Je quittai ma couche de granit et j'allai jouir du magnifique spectacle qui se développait à mes regards" (Verne [1864] 1919, 130; as translated in Verne 1992, 81; I got up from my granite bed to go and enjoy the magnificent spectacle laid out before my eyes); “C'est magnifique! m'écriai-je involontairement. Quel spectacle, mon oncle!” (Verne [1864] 1919, 149; as translated in Verne 1992, 92; "It's magnificent!" I shouted in spite of myself. "What a sight, Uncle!").

16 The transcript (NASA 1989b) has "Gosh, I hope so," but in the video one can clearly hear "I sure hope so" (Motherboard 2010, c.49 min.). 
same time, the continued search for the unknown marks a shift from a melancholy feeling in the first part of the soliloquy to a fresh hope of real discoveries. What do these lines mean as spoken by Annlee in the voice of Armstrong? Is she indeed Armstrong's ghost? In the next part s/he will move on to recite passages from Voyage au centre de la terre-is this Armstrong reading Verne or Annlee describing her own lunar experiences?

The second part of the lunar soliloquy reads as follows (I have put in italics the direct quotations from Voyage au centre de la terre):

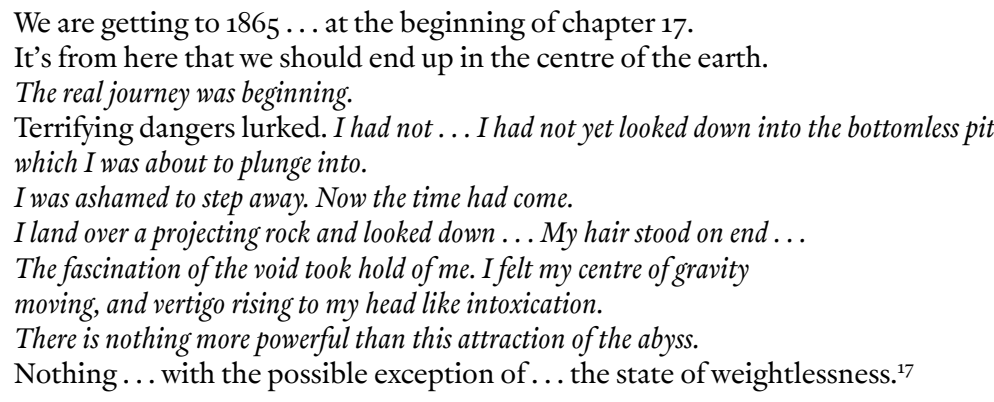

As can readily be seen, much of this part consists of direct quotations from Verne's novel, describing the descent into the underworld. The rest, with the exception of the last line, are paraphrases from the same chapter. The text is mainly in the past tense used by the first person narrator in Verne's novel. What is the significance of the transposition of the narrator's experiences of entering the underworld, which are a series of shocks and surprises, to Annlee walking on the moon? The most striking element is the contrast to how well

17 Again the text in the catalogue No Ghost Just a Shell (Huyghe and Parreno 2003, 14 -45) is slightly different:

We are arriving in $1865 \ldots$ the beginning of chapter 17 .

It's from here that we should end up in the centre of the earth.

The real journey was beginning.

Fearful dangers lurked. I had not yet looked down into the bottomless pit

which I was about to plunge into.

I was ashamed to step away. Now the time had come.

I land over a projecting rock and looked down... My hair stood on end ..

The fascination of the void took hold of me. I felt my centre of gravity

moving, and vertigo rising to my head like intoxication.

There is nothing more powerful than this attraction of the abyss.

Nothing ... with the possible exception of ... the state of weightlessness.

And here are the corresponding lines in Voyage au centre de la terre (also in italics):

Le véritable voyage commençait. Jusqu'alors les fatigues l'avaient emporté sur les difficultés; maintenant celles-ci allaient véritablement naître sous nos pas.

Je n'avais point encore plongé mon regard dans ce puits insondable où j'allais m'engouffrer. Le moment était venu. Je pouvais encore ou prendre mon parti de l'entreprise ou refuser de la tenter. Mais j'eus honte de reculer devant le chasseur....

... Je me penchai au-dessus d'un roc qui surplombait, et je regardai; mes cheveux se hérissèrent. Le sentiment du vide s'empara de mon être. Je sentis le centre de gravité se déplacer en moi et le vertige monter à ma tête comme une ivresse. Rien de plus capiteux que cette attraction de l'abime. (Verne [1864] 1919, 138-39; 1992, 86) 


\section{Leif Dahlberg}

prepared the Apollo 11 astronauts were for the moon landing. That is, whereas the volcano crater on Iceland had prepared the astronauts for what they would encounter on the moon, Verne's narrator appears entirely unprepared for the strange topography below. In Annlee's soliloquy, these two experiences are juxtaposed, although technically they follow each other. That is, there is a transition from déjà vu—where the unknown appears familiar-to encountering the familiar as unknown. We have here another version of the uncanny, as identified by Freud. As he notes in the philological part of his study of the notion, part of the meaning of das Unheimliche resides in the negation of what is heimlich, "homely." Yet paradoxically, heimlich also means "hidden," "secret," or "surreptitious." In other words, among its different meanings, the word heimlich exhibits one that is identical with its opposite, unheimlich. ${ }^{18}$ Freud concludes that what is frightening about the uncanny is not that something is unfamiliar and new, but that what used to be familiar somehow has become strange. ${ }^{19}$ In the case of the astronauts' experiences on the moon, the uncanny resides in the opposite, that it was all too familiar.

So what do these lines from Verne's novel refer to when spoken by Annlee walking in a lunar landscape that is being generated by Armstrong's voice? Are we in the underworld or in the lunar world, or perhaps both at the same time, the two being topologically similar? Is Annlee in fact responding to the "real mysteries" mentioned earlier in her soliloquy? However, the last line, speaking of weightlessness, seems to bring us back to the lunar experience.

The last part of the lunar soliloquy consists of two sentences:

For a moment I was afraid that their words might be my own, brought back by an echo.

I listened once more, and this time I clearly heard my name thrown through space. ${ }^{20}$

18 "Thus heimlich is a word the meaning of which develops in the direction of ambivalence, until it finally coincides with its opposite, unheimlich. Unheimlich is in some way or other a sub-species of heimlich" (Freud [1919] 1966, 237, as translated in Freud 1955, 226).

19 "The uncanny is that class of the frightening which leads back to what is known of old and long familiar" (Freud [1919] 1966, 231, as translated in Freud 1955, 220). "This uncanny is in reality nothing new or alien, but something which is familiar and old-established in the mind and which has become alienated from it only through the process of repression" (Freud [1919] 1966, 254, as translated in Freud 1955, 241).

20 And again the text in the catalogue No Ghost Just a Shell (Huyghe and Parreno 2003, 145) is slightly different:

For a moment I was afraid that their words might be my own, brought back to me by an echo. Ilistened once more, and this time I clearly heard my name thrown through the space.

And here are the corresponding two passages in Voyage au centre de la terre: "J'eus un instant la crainte que ces paroles ne fussent les miennes, rapportées par un écho" (Verne [1864] 1919, 209; 1992, 129); "J'écoutai de nouveau, et cette fois, oui! cette fois, j'entendis mon nom distinctement jeté à travers l'espace!" (Verne [1864] 1919, 211; 1992, 130). 
These lines are also direct citations from Verne's novel, describing the experiences of the narrator having lost contact with the other members of the group. However, as spoken by Annlee, they take on a radically different meaning. On the one hand, she is a person who in her short life (basically since 200o) has been searching for an identity, well aware that her name is an empty signifier. On the other hand, these lines are spoken by a person walking all alone on the lunar surface, whose voice is interacting with the moonscape in a very intimate way. Moreover, since Annlee does not speak with her own voice, the fear that "their words might be my own" has a strange sense of dispossession; that is, since she is unable to own her own voice, she may be appropriated by other voices, in this case both Armstrong and the narrator in Verne's novel (and of course also the director and producer of the film, Huyghe and Vaney). The words she is speaking are indeed not her own, nor are they spoken by her, yet at the same time they are coming back to her in the form of the landscape echoing the words. The second line, the last one in the soliloquy, which for Verne's narrator is a confirmation that he has regained auditory contact with the group, again has a different meaning when spoken by Annlee. She says she is hearing her name, but spoken by whom? Does this signify that she is not alone, or is it her own words she's hearing, calling her name? Is it Armstrong calling her forth? The passage also echoes scenes from previous visits to the underworld, where Odysseus, Aeneas, and Dante are recognised by the permanent dwellers on the other side. The latter are confused by the visit of a living person, but most of all they are eager to hear news from up above. Annlee, by way of contrast, encounters no one in this desolate landscape, even if she clearly hears her "name thrown through space." Again we encounter a disquieting strangeness, we do not know whether we should feel reassured or worried.

In analysing the film One Million Kingdoms we have seen both that it is constructed by transposition and that it thematises this device by making the strange appear familiar and the familiar appear strange. We have noted the proximity to the psychological notion of the uncanny, to which we will return. But before we do this, the device needs to be placed in another context. In a celebrated essay from 1917, Shklovsky (1990a) formulated both a critique of the current symbolist poetics - that poetry consisted in a "thinking in images"and an alternative, that what is going on in art is an effort to make us see things rather than merely recognise them. That is, since human perception has a tendency toward automatisation, motivated by economy of effort, we do not actually see the world around us and the things and creatures inhabiting it; we have become used to it and in this way have become alienated from our own lifeworld. Commenting on a diary entry by Leo Tolstoy, Shklovsky (1990a, 5) writes: "Automatization eats away at things, at clothes, at furniture, at our wives, and at our fear of war." To prevent us from living our lives as unconscious beings, the purpose of art is to reverse the effect of automatisation, creating a defamiliarisation or "making strange" (ostranenie): 


\title{
Leif Dahlberg
}

\begin{abstract}
And so, in order to return sensation to our limbs, in order to make us feel objects, to make a stone feel stony, man has been given the tool of art. The purpose of art, then, is to lead us to a knowledge of a thing through the organ of sight instead of recognition. By "enstranging" objects and complicating form, the device of art makes perception long and "laborious." The perceptual process in art has a purpose all its own and ought to be extended to the fullest. Art is a means of experiencing the process of creativity. The artifact itself is quite unimportant. (Shklovsky 1990a, 6, italics original)
\end{abstract}

It should be noted first that Shklovsky's definition of art does not focus on what it is but on what it does. Thus, in contrast to the Aristotelian notion that poetry, and art in general, is a representation of reality ("that this person is [i.e. represents] that one" [Poetics 1448b17, my translation; see Aristotle 1995, $38,39]),{ }^{21}$ Shklovsky defines art in functional and teleological terms: art is a means towards an end, to experience the world in a way similar to how children explore their surroundings, feeling and touching objects with open senses and full of wonder. It is also worth noting that the last sentence in the quotation from Shklovsky implies a radical rethinking of the nature of the artwork: not only does it not need to be beautiful but it does not have to be made by an artist nor have a physical existence at all, and is thus open for ready-mades and conceptual art. In the essay, Shklovsky illustrated his notion mainly with literary examples, but among his contemporaries it was adopted primarily by avant-garde film-makers and later in the theatre (which is where Bertolt Brecht encountered it) (Reich 1970, 371). However, the notion can readily be transposed to other forms of art, including music and abstract art, at least to the extent that they let us "see" things.

It has repeatedly been argued that Shklovsky's definition of art as making things appear strange excludes art's cognitive dimension. According to this view, art not only makes us perceive and feel reality ("to make a stone feel stony") but also makes us understand what we see in new ways. This critique is typically found among scholars with a rather narrow knowledge of the Russian formalist school. However, it suffices to pay attention to how Shklovsky uses his examples to see that in his view perception is coupled to cognition, that a new way of seeing things also implies a new way of understanding the matter at hand. Further, it is also frequently argued that Shklovsky did not care for art's social dimensions. ${ }^{22}$ Again the literary examples used by Shklovsky in his essay contradict any such claims, since they are largely political in nature, as has recently been shown by Cristina Vatulescu (2006). In other words, Brecht's appropriation of the term (as Verfremdung [distancing]) did not imply a "politicisation" of Shklovsky's notion, but a transposition from literature to drama, and from Russia to Germany. It could also be noticed in passing that there are certain affinities between Shklovsky's notion that art makes us see reality and Martin Heidegger's idea that art discloses reality, bringing forth entities out of

21 For a recent critical discussion of this passage, see Tsitsiridis (2005).

22 See, for example, Mitchell (1974, 74-81). For a study of the reception history of the term ostranenie in the West, see van den Oever (2010). 
concealment. ${ }^{23}$ However, in contrast to Brecht, this is not a question of appropriation but rather a return to the philosophical roots of the concept-that is, to Edmund Husserl's call that we need to return to "things themselves." 24 Further, both Shklovsky and Heidegger pay close attention to art as an act of making (technē).

There are striking similarities and differences between the conception of "making strange" found in Shklovsky and "the uncanny" (das Unheimliche) in Freud. The similarity consists in that in both cases it is a question of making the familiar appear strange (or that the familiar suddenly appears strange, as if by itself). The difference is that in one (Shklovsky and Brecht, but also Husserl and Heidegger) the purpose and effect is to make us see reality as it really is, phenomenally and without preconceived ideas, making possible a "creative" understanding of phenomena (although not in a frightening way); and in the other (Jentsch and Freud), "making strange" implies a sensation of discomfort or fear, according to Freud brought about by the return of either surmounted beliefs belonging to primitive humans (omnipotence of thoughts, instantaneous wish-fulfilment, secret harmful forces, and the return of the dead) or repressed childhood complexes (castration complex, womb fantasies, etc.), having as common denominator "a conflict of judgement as to whether things which have been 'surmounted' and are regarded as incredible may not, after all, be possible" (Freud [1919] 1966, 264, as translated in Freud 1955, 250). However, the difference between the two uses or functions of "making strange" is not absolute and they may very well co-exist, for instance by suggesting topological similarities between seemingly separate events and through the inversion of the distinction between reality and fiction, as we have witnessed in the film One Million Kingdoms.

In his essay, and also in later works, Shklovsky describes a variety of devices or techniques used by artists to make things appear strange. His favourite examples of such techniques are calling attention to language and "complicating form," thus making "perception long and "laborious" instead of automatic (for instance by narrative retardation); presenting familiar objects from the point of view of an outsider, such as an animal, a child, or a foreigner; and foregoing the conventional names for things and describing them as if seen for the first time. I would argue that transposition should be added to this list as another artistic device to make familiar things appear strange, as well as the various devices Jentsch and Freud identified as producing the uncanny in literary works.

23 See Heidegger's "Der Ursprung des Kunstwerkes" ("The Origin of the Work of Art"), in particular: " $\tau \varepsilon ́ \chi v \eta$, as knowledge experienced in the Greek manner, is a bringing forth of beings [des Seienden] in that it brings forth present beings as such beings [das Anwesende als ein solches] out of concealedness and into unconcealment and specifically into the unconcealment of their appearance; $\tau \dot{\varepsilon} \chi v \eta \eta$ never signifies the action of making." (Heidegger [1935] 2003, 47, as translated in Harries 2009, 141).

24 "We must go back to the "things themselves" (Husserl 1900-1901, 2:7, as translated in Husserl [1970] 2001, 1:168; Wir wollen auf die "Sachen selbst" zurückgehen). 
In 2002, after the announcement that the Van Abbemuseum in Eindhoven had purchased all the video pieces and artworks featuring Annlee, Huyghe and Parreno declared that they had decided to terminate the project, selling the rights to Annlee to a newly created company, owned by themselves and Annlee, with the explicit purpose to prevent further exploitation of the animated figure and in this way liberate her from being owned. A legal document was set up, reproduced in the exhibition catalogue No Ghost Just a Shell (Huyghe and Parreno 2003, 303-14). Huyghe has described the motive behind the decision in the following way: "We became the owners of it.... We wanted the character to be the owner of its own rights" (ibid., 24). In an interview, Parreno has elaborated this point: "We're trying to give rights to a thing.... The history of authors' right moves from the king to the printer to the publisher, then from the publisher to the author, and today, from the authors to the character" (ibid.). However, the two artists' claim to have emancipated Annlee and given her the rights to her own character can be challenged in a number of ways. First, the effect of this act was not to give her life, or more life, but rather to kill her off. Since she did not have the power actually to execute her rights, she would not be able to appear in any future artworks.

A critic has rhetorically put forward the question whether Huyghe and Parreno asked Annlee whether she really did wish to disappear (Yap 2012). Might she not have desired to own her copyright when she was alive rather than dead? Further, some critics have attacked the multiple stereotypes inherent in the narrative of a young, powerless Asian female who is first given form and then silenced by two male Westerners (cited in ibid.). The greatest problem with "terminating" the project is the fiction that it implied an emancipation in any substantial way. Instead of liberating Annlee, she was now even further under the control of the two artists and their corporate lawyer. It appears that to some extent they had anticipated some of these reactions, since in the catalogue they engage in conversation with the biologist Jean Claude Ameisen about the meaning of life and death, and to what extent one can kill something that has never been alive, or at least able to live by itself (compare discussions about abortion and the right to life). Regardless whether one accepts Huyghe's and Parreno's stated motifs for emancipating Annlee and takes seriously the discussion of life and death of a visual sign, we here encounter two additional examples of transposition: first from art to law, or rather the invocation of law in art, since the juridical document, although legal, primarily has an artistic function; ${ }^{25}$ and second from art to biology, or rather the transposition of a biological discussion about life and death to the world of art.

As in every good legal parable, the story of Annlee's "emancipation" has several interpretations. First, it can be questioned to what extent the contract setting up the company that owns Annlee really prevents any artist from doing work on/with her character. In legal terms, it is enough that one sufficiently transforms the original visual image in order to be able to claim to make an

25 There is a precursor in the setting up of L'Association des temps libérés (The Association of Liberated Time), created by Huyghe in 1995 (see Barikin 2012, 2-3, 44-47 et passim; Rotenberg 2013). 
original work of art. In fact, rather than ending her imaginary life, the attempt to terminate her existence has provoked several artists to appropriate her character. For instance, Puerto Rican artist Pedro Velez and art collective Law Office, whose artwork Ann Lee Lives (2003) shows a picture of a girl looking up at the viewer passively, over which is written: "Philippe + Pierre, you can't kill Ann Lee! She's alive and well, in Puerto Rico. Go fuck yourselves! L.O. + P.V." (Yap 2012). Another example is Judy Zhu's music video What a Wonderful World (Covered by "Alice" the Sonic Diva) (Zhu 2016), which uses video material from Anywhere Out of the World and One Million Kingdoms and sound from an online text reader website (fromtexttospeech.com) - the voice from the persona called "Alice" singing What a Wonderful World (written by Bob Thiele and George David Weiss, first performed by Louis Armstrong in 1967). The effect of this remake of One Million Kingdoms is quite striking, radically different from the brooding character we met in Huyghe's film. Finally, the artists who previously produced work in collaboration with Huyghe and Parreno have not in any way lost their rights to their work, and can of course display them as they wish, prolonging the afterlife of Annlee.

\section{REFERENCES}

Aristotle. 1995. Poetics, edited and translated by Stephen Halliwell. In Aristotle: Poetics; Longinus: On the Sublime; Demetrius: On Style, 2nd ed., 27-141. Loeb Classical Library 199. Cambridge, MA: Harvard University Press.

Baker, George, and Pierre Huyghe. 2004. "An Interview with Pierre Huyghe." October 110: 80-106.

Bakhtin, Mikhail. 1981. The Dialogic Imagination: Four Essays. Edited by Michael Holquist. Translated by Caryl Emerson and Michael Holquist. Austin: University of Texas Press. First published 1975 as Voprosy literatury i èstetiki (Moscow: Hudožestvennaă literatura). - 1984. Problems of Dostoevsky's Poetics. Edited and translated by Caryl Emerson. Minneapolis: University of Minnesota Press. First published 1963 as Problemy poétiki Dostoevskogo (Moscow: Sovetskij pisatel').

Barikin, Amelia. 2012. Parallel Presents: The Art of Pierre Huyghe. Cambridge, MA: MIT Press.

Centre Pompidou. 2013. "Pierre Huyghe: Du 25 septembre 2013 au 6 janvier 2014, Galerie sud." Accessed 31 January 2017. http://mediation.centrepompidou.fr/ education/ressources/ENS-Huyghe/.
Dahlberg, Leif. 2010. "Put a Tiger in Your Text: Metalepsis and Media Discourse." Nordicom Review 31 (1): 103-14.

Derrida, Jacques. (1971) 1972. "La mythologie blanche: La métaphore dans le texte philosophique.” In Marges de la philosophie, 247-324. Paris: Minuit. First published 1971 (Poétique 5). Translated by Alan Bass as "White Mythology: Metaphor in the Text of Philosophy" in Margins of Philosophy (Chicago: University of Chicago Press, 1982), 207-72.

Erickson, Ruth. 2009. "The Real Movie: Reenactment, Spectacle, and Recovery in Pierre Huyghe's The Third Memory." Framework 50 (1-2): 107-24.

Fontanier, Pierre. (1827) 1977. Les Figures de discours. Edited by Gérard Genette. Paris: Flammarion. First published 1827 (Paris: Maire-Nyon).

Freud, Sigmund. (1919) 1966. "Das Unheimliche.” In Gesammelte Werke: XII, Werke aus den Jahren 1917-1920, edited by Anna Freud, Edward Bibring, Willi Hoffer, Ernst Kris, and Otto Isakower, 229-68. Frankfurt: Fischer. Essay first published 1919 (Imago 5 [5-6]: 297-324). Volume first published 1947 (London: Imago). Translated by James Strachey et al. as Freud 1955. 


\section{Leif Dahlberg}

__ 1955. "The 'Uncanny.” In The Standard Edition of the Complete Psychological Works of Sigmund Freud, Vol. XVII (1917-1919): An Infantile Neurosis and Other Works, translated and edited by James Strachey in collaboration with Anna Freud, assisted by Alix Strachey and Alan Tyson, 217-56. London: Hogarth Press. For original publication details see Freud (1919) 1966.

Gilbert, W. S. 1992. Libretto, in liner notes to The Mikado, performed by Donald Adams, Anthony Rolfe Johnson, Richard Suart, et al., the Orchestra and Chorus of the Welsh National Opera, conducted by Charles Mackerras, 12-33. Telarc, CD80284 , compact disc.

Godfrey, Mark. 2008. "Pierre Huyghe's Double Spectacle." Grey Room 32: 38-61. Guggenheim. 2017. "Pierre Huyghe: Highlights.” Accessed 2 February. http:// pastexhibitions.guggenheim.org/ moving_pictures/highlights_13a.html.

Harries, Karsten. 2009. Art Matters: A Critical Commentary on Heidegger's "The Origin of the Work of Art." [Dordrecht]: Springer.

Heidegger, Martin. (1935) 2003. "Der Ursprung des Kunstwerkes." In Holzwege, 8th ed., 1-74. Frankfurt am Main: Klostermann. Essay first delivered 1935 as a lecture. Book first published 1950 (Frankfurt am Main: Vittorio Klostermann).

Husserl, Edmund. 1900-1901. Logische Untersuchungen. 2 vols. Halle an der Saale: Max Niemeyer. Translated by J. N. Findlay as Husserl (1970) 2001.

———. (1970) 2001. Logical Investigations. Translated by J. N. Findlay. Edited by Dermot Moran. 2 vols. London: Routledge. First published as Husserl 1900-1901. This translation based on 2nd ed. (Halle an der Saale: Max Niemeyer, 1913-21). Translation first published 1970 (London: Routledge and Kegan Paul).

Huyghe, Pierre, dir. 2001. One Million Kingdoms. Anna Lena Vaney (producer), Michel Raimbault (animation director), Sparx (post-production company). Accessed 20 June 2016. http://www.li-ma. nl/site/catalogue/art/pierre-huyghe/onemillion-kingdoms/10891; http://www. dailymotion.com/video/xkn78i_onemillion-kingdoms_creation.

Huyghe, Pierre, Stefan Kalmar, Philippe
Parreno, Beatrix Ruf, and Hans Ulrich Obrist. 2003. "Conversations." In Huyghe and Parreno 2003, 14-30.

Huyghe, Pierre, and Philippe Parreno. 2003. No Ghost Just a Shell. Cologne: Walter König. Published in conjunction with the exhibition of the same name, shown at the Kunsthalle Zürich; SF MOMA, San Francisco; Van Abbemuseum, Eindhoven. Jentsch, Ernst. 1906. "Zur Psychologie des Unheimlichen." Psychiatrisch-Neurologische Wochenschrift 8 (22): 195-98; 8 (23): 203-5. Translated by Roy Sellars as Jentsch 2008. - 2008. "Document: 'On the

Psychology of the Uncanny' (1906).” Translated by Roy Sellars. In Uncanny Modernity: Cultural Theories, Modern Anxieties, edited by Jo Collins and John Jervis, 216-28. Basingstoke, UK: Palgrave Macmillan. First published as Jentsch 1906.

Lazzarato, Maurizio. 2003. "Dialogism and Polyphony." In Huyghe and Parreno, 2003, 58-73.

Milton, John. (1674) 2004. Paradise Lost. Edited by Stephen Orgel and Jonathan Goldberg. Oxford: Oxford University Press. Edition based on 2nd rev. ed. first published 1674 (London).

Mitchell, Stanley. 1974. "From Shklovsky to Brecht: Some Preliminary Remarks towards a History of the Politicisation of Russian Formalism.” Screen 15 (2): 74-81.

Motherboard. 2010. "Apollo 11 Press Conference." YouTube video, 1:23:30, posted by "Motherboard," 22 July. Accessed 2 February 2017. https://www. youtube.com/watch?v=BI_ZehPOMwI.

NASA. 1989a. The First Lunar Landing: As Told By the Astronauts Armstrong, Aldrin, and Collins in a Post-flight Press Conference. Accessed 2 February 2017. http://history. nasa.gov/ap11ann/FirstLunarLanding/ toc.html.

—— - 1989b. "Part VI." In NASA 1989a, accessed 2 February 2017, http://history. nasa.gov/ap11ann/FirstLunarLanding/ ch-7.html.

_—_. 2012. "One Small Step." In Apollo 11 Lunar Surface Journal. Accessed 2 February 2017. https://www.hq.nasa.gov/alsj/a11. step.html.

Ovid. 2014. Metamorphoses X. Edited by Lee Fratantuono. London: Bloomsbury.

Reich, Bernhard. 1970. Im Wettlauf mit der 
Zeit: Erinnerungen aus füf Jahrzehnten deutscher Theatergeschichte. Berlin: Henschelverlag.

Ricœur, Paul. 1975. La Métaphore vive. Paris: Seuil. Translated by Robert Czerny with Kathleen McLaughlin and John Costello as The Rule of Metaphor: Multi-disciplinary Studies of the Creation of Meaning in Language (Toronto: University of Toronto Press, 1977).

Rotenberg, Lauren. 2013. "The Prospects of 'Freed' Time: Pierre Huyghe and L'association des temps libérés." Public Art Dialogue 3 (2): 186-216.

Shklovsky, Viktor. 1990a. “Art as Device.” In Theory of Prose, translated by Benjamin Sher, 1-14. Elmwood Park, IL: Dalkey Archive Press. Book first published 1925 as O teorii prozy (Moscow: Krug). Translation based on 2nd ed. (Moscow: Federacija, 1929). - 1990b. "The Making of Don Quixote.” In Theory of Prose, translated by Benjamin Sher, 72-10o. Elmwood Park, IL: Dalkey Archive Press. For original publication details see Shklovsky 1990 a.

Stevens, Benjamin Eldon. 2015. "Virgil in Jules Verne's Journey to the Center of the Earth." In Classical Traditions in Science Fiction, edited by Brett M. Rogers and Benjamin Eldon Stevens, 75-104. New York: Oxford University Press.

Tsitsiridis, Stavros. 2005. "Mimesis and Understanding: An Interpretation of Aristotle's Poetics 4.1448B4-19." Classical Quarterly, n.s., 55 (2): 435-46.

van den Oever, Annie, ed. 2010. Ostrannenie:
On "Strangeness" and the Moving Image; The History, Reception, and Relevance of a Concept. Amsterdam: Amsterdam University Press.

Vatulescu, Cristina. 2006. "The Politics of Estrangement: Tracking Shklovsky's Device through Literary and Policing Practices." Poetics Today 27 (1): 35-66. Verne, Jules. (1864) 1919. Voyage au centre de la terre. $55^{\text {th }}$ ed. Paris: Hachette. First published 1864 (Paris: J. Hetzel). Translated by William Butcher as Verne 1992.

- 1992. Journey to the Centre of the Earth. Translated by William Butcher. Oxford: Oxford University Press. For original publication details see Verne (1864) 1919.

Yap, Chin-Chin. 2012. "Escaping Ghost." ArtAsiaPacific, March/April. Accessed 3 February 2017. http://artasiapacific.com/ Magazine/77/EscapingGhost.

Zhu, Judy. 2016. What a Wonderful World (Covered by "Alice" the Sonic Diva). YouTube video, 2:15, posted by "Judy Zhu," 12 April. Accessed 3 February 2017. https://www.youtube.com/ watch? $\mathrm{v}=\mathrm{hMsMNBt} 3 \mathrm{iGU}$. Vimeo video, 2:16, posted by “Judybeijing," 12 April. Accessed 3 February 2017. https://vimeo. com $/ 162553114$.

Zironi, Alessandro. 2010. "Searching for Origins: Indo-European Words and Nordic Representations.” In Origins as a Paradigm in the Sciences and in the Humanities, edited by Paola Spinozzi and Alessandro Zironi, 211-26. Göttingen: V \& R Unipress. 